\title{
Pengaruh Komposisi Kuning Telur pada Pengencer Air Kelapa Hijau Terhadap Kualitas Semen Cair Kambing Boer
}

\author{
Nisa'us Sholikah, Sri Susilowati \\ Fakultas Peternakan, Universitas Islam Malang \\ Jl. MT. Haryono No. 193, Malang. No. Telpon/ Faks. 0341-580530 / 0341552249. \\ *Email korespondensi: nisaus.sholikah@unisma.ac.id
}

(Diterima 27-03-2020; disetujui 15-05-2020)

\begin{abstract}
ABSTRAK
Air kelapa dapat digunakan sebagai bahan alternatif pengencer semen cair karena mengandung unsur karbon yang dibutuhkan untuk menjaga kualitas spermatozoa. Penelitian ini bertujuan untuk mengetahui pengaruh perbedaan komposisi kuning telur pengencer air kelapa hijau terhadap kualitas semen cair kambing boer. Penelitian dilaksanakan di Laboratorium Reproduksi Ternak Fakultas Peternakan Universitas Brawijaya, Malang, pada bulan November 2019. Penelitian ini menggunakan metode eksperimental laboratorium dengan rancangan acak kelompok (RAK). Data dianalisis menggunakan analisis ragam (ANOVA). Terdapat 4 perlakukan, $\mathrm{P} 0=\mathrm{CEP}-3+10 \%$ kuning telur, $\mathrm{P} 1=$ Pengencer air kelapa $+5 \%$ kuning telur, $\mathrm{P} 2=$ Pengencer air kelapa $+10 \%$ kuning telur, dan $\mathrm{P} 3=$ Pengencer air kelapa $+15 \%$ kuning telur. Hasil menunjukkan bahwa terdapat perbedaan yang signifikan $(\mathrm{P}<0,01)$ pada motilitas individu dan viabilitas spermatozoa, akan tetapi tidak berpengaruh signifikan $(\mathrm{P}>0,05)$ pada abnormalitas spermatozoa antara perlakuan selama peyimpanan dingin. Kesimpulan penelitian adalah perlakuan terbaik didapatkan pada P3 yang dapat mempertahankan kualitas semen cair kambing boer sampai penyimpanan hari ke-3.
\end{abstract}

Kata kunci: air kelapa hijau, kuning telur, kambing boer, semen

\begin{abstract}
Coconut water extender can be used as an alternative semen extender because it contains the carbon element needed to maintain the quality of spermatozoa. The aims of this research were to examine the effect of different compositions of yolk in green coconut water extender on the quality of boer goat semen during cold storage. This research was carried out at the Laboratory of Animal Reproduction of Animal Husbandry Faculty of Brawijaya University in November 2019. The research used a laboratory experimental method. The experimental design was a randomized complete block design. The data were analyzed by Analyze of Variance. In this research there were four treatments (P0 $=$ CEP-3 $+10 \%$ yolk; P1 $=$ Coconut Water $+5 \%$ yolk; P2 = Coconut Water $+10 \%$ yolk; dan $\mathrm{P} 3=$ Coconut Water $+15 \%$ yolk). The result of this research show were significant differences $(\mathrm{P}<0.01)$ in sperm motility and viability, but no significant differences $(\mathrm{P}>0.05)$ in sperm abnormality between coconut water extenders with different compositions of yolk. In conclusion, the best treatment was P3 in maintaining boer goat sperm quality after three days of chilled preservation.
\end{abstract}

Keywords: boer goat, green coconut water, semen, yolk

\section{PENDAHULUAN}

Kambing boer merupakan kambing tipe pedaging yang memiliki kelebihan yaitu tahan terhadap kondisi lingkungan kasar dengan manajemen pemeliharaan minim tetapi memiliki produktivitas dan reproduksi yang tinggi, oleh karena itu, kambing boer perlu dikembangkan menjadi salah satu komoditas peternakan yang diharapkan dapat memberikan kontribusi bagi penyediaan daging di Indonesia penerapan teknologi inseminasi buatan (IB). IB sebagai salah satu teknologi reproduksi sangat besar peranannya dalam meningkatkan efisiensi reproduksi ternak jantan dengan mengatasi keterbatasan jumlah pejantan unggul, serta memanfaatkan secara maksimal kapasitas reproduksi pejantan (Rizal, 
2009). Penggunakaan IB dengan semen beku telah dikenal di seluruh Indonesia. Selama penerapannya, ada beberapa kendala penggunaan semen beku antara lain kesulitan dalam penyediaan nitrogen cair dan kontainer, serta proses pembuatannya yang rumit. Alternatif untuk mengatasi kendala-kendala tersebut salah satunya adalah penggunaan semen cair.

Semen cair disimpan dalam suhu dingin. Kondisi sel spermatozoa yang mudah mengalami kerusakan pada saat perlakuan maupun penyimpanan membutuhkan pengencer yang dapat mempertahankan kualitasnya. Pengencer harus mengandung sumber nutrisi, buffer, anti cold shock, antibiotik dan krioprotektan yang dapat melindungi spermatozoa dalam proses pendinginan dan pembekuan (Susilawati, 2013). Beberapa jenis pengencer seperti Tris Aminomethane kuning telur, cauda epididymal plasma (CEP-1, CEP-2, CEP-3) dan Andromed telah terbukti mampu mempertahankan kualitasspermatozoa selama simpan dingin. Pengencer-pengencer tersebut masih memiliki kekurangan yaitu bahan-bahan untuk pembuatannya sangat mahal dan sulit didapatkan, sehingga berbagai penelitian perlu untuk mengganti bahan-bahan pengencer impor dengan bahan-bahan lokal yang mudah serta murah didapat.

Bahan lokal yang dapat menjadi bahan baku alternatif dalam proses pembuatan pengencer semen adalah air kelapa. Selain itu, menurut Vigliar et al. (2006) air kelapa mengandung unsur karbon berupa karbohidrat sederhana, seperti: glukosa, sukrosa, dan fruktosa. Hasil penelitian Audia et al. (2017) menunjukkan bahwa penggunaan pengencer air kelapa hijau mampu mempertahankan motilitas spermatozoa kambing boer di atas $40 \%$ hingga penyimpanan hari ke-2 selama penyimpanan pada suhu $3-{ }^{\circ} \mathrm{C}$.

Upaya penyimpanan semen cair kambing boer yang diencerkan dengan pengencer air kelapa hijau muda dengan penambahan kryoprotektan ekstraseluler kuning telur dengan konsentrasi yang berbeda untuk mendapatkan formulasi pengencer terbaik belum pernah dilaporkan. Berdasarkan fakta tersebut, maka perlu dilakukan penelitian yang bertujuan untuk mengetahui pengaruh komposisi kuning telur pengencer air kelapa hijau terhadap kualitas semen cair kambing boer.

\section{MATERI DAN METODE}

\section{Lokasi dan Waktu Penelitian}

Penelitian dilaksanakan pada tanggal 1-30 November 2019 di Laboratorium Reproduksi Ternak Fakultas Peternakan Universitas Brawijaya.

\section{Materi Penelitian}

Materi penelitian adalah semen segar pejantan kambing boer berumur 3-5 tahun sebanyak 3 ekor yang dipelihara di Laboratorium Lapang Fapet Universitas Brawijaya, desa Sumber Sekar, Dau, Malang. Semen segar yang diproses harus mempunyai motilitas individu $\geq 70 \%$ dan motilitas massa 2+. Air kelapa yang digunakan adalah dari jenis Kelapa Hijau (viridis) dengan kematangan buah kelapa muda (5-7 bulan). Kuning telur (KT) yang digunakan berasal dari telur segar ayam ras petelur (layer) dengan umur telur $<3$ hari.

\section{Metode Penelitian dan Analisis Data}

Metode penelitian yang digunakan adalah metode eksperimen laboratorium. Rancangan penelitian adalah Rancangan Acak Kelompok (RAK) dengan 4 perlakuan dan 5 ulangan yang digunakan sebagai kelompok. Data dianalisis menggunakan analisis ragam, apabila terdapat perbedaan nyata atau sangat nyata, maka dilakukan pengujian menggunakan uji jarak Duncan (Duncan Multiple Range). Perlakuan penelitian yaitu P0 (CEP-3 + 10\% Kuning Telur); P1 (Air Kelapa Hijau Muda $+5 \%$ Kuning Telur); P2 (Air Kelapa Hijau Muda $+10 \%$ Kuning Telur); dan P3 (Air Kelapa Hijau Muda $+15 \%$ Kuning Telur).

\section{Parameter Penelitian}

Parameter penelitian yang diamati adalah kualitas spermatozoa meliputi persentase motilitas individu, persentase viabilitas, dan persentase abnormalitas.

\section{HASIL DAN PEMBAHASAN}

\section{Kualitas Semen Segar Kambing Boer}

Uji kualitas semen kambing boer dilakukan sebelum proses pengenceran dan preservasi. Pemeriksaan semen segar meliputi pengamatan makroskopis dan mikroskopis. Pengamatan makroskopis semen segar antara lain volume $(\mathrm{ml})$, bau, warna, konsistensi dan $\mathrm{pH}$. Pengamatan miksroskopis meliputi motilitas massa, persentase motilitas individu spermatozoa, persentase viabilitas spermatozoa, persentase abnormalitas spermatozoa dan konsentrasi spermatozoa (juta/ml). Hasil uji kualitas semen kambing boer dapat dilihat pada Tabel 1 .

Pada Tabel 1 diperoleh karateristik semen segar Kambing boer antara lain warna semen adalah putih kekuningan dengan bau khas semen yang menunjukkan bahwa semen tersebut dalam kondisi normal. 
Tabel 1. Rataan kualitas semen segar kambing boer

\begin{tabular}{lc}
\hline \multicolumn{1}{c}{ Pengamatan } & Rata-Rata \pm SD \\
\hline Uji Makroskopis & Putih Kekuningan \\
Warna & Sedang-kental \\
Konsistensi & Khas Semen \\
Bau & $0,93 \pm 0,16$ \\
Volume Perejakulasi (ml) & $6,65 \pm 0,08$ \\
pH & ++ \\
\hline Uji Mikroskopis & $73,33 \pm 6,06$ \\
Motilitas Massa & $81,72 \pm 7,91$ \\
Motilitas Individu (\%) & $2,16 \pm 0,50$ \\
Viabilitas (\%) & $4607,30 \pm 530,79$ \\
Abnormalitas (\%) & \\
Konsentrasi (juta/ml) &
\end{tabular}

Hasil ini sesuai Ihsan (2010) bahwa plasma semen kambing pada umumnya berwarna putih kuning, hal ini disebabkan karena adanya riboflavin yang disekresikan kelenjar vesikularis. Agustian et al. (2014) menyatakan semen normal memiliki bau amis khas semen disertai bau dari ternak pejantan. Berdasarkan hasil pengamatan uji kualitas semen didapatkan rataan volume semen sebesar $0,93 \pm 0,16$ ml/ejakulat. Hasil masih terogolong baik dan normal. Menurut Ihsan (2010), rataan volume semen kambing sebesar $1 \pm 0,3 \mathrm{ml}$ dengan kisaran 0,6-1,5 ml merupakan kisaran normal dapat ditampung waktu ejakulasi. $\mathrm{pH}$ semen segar

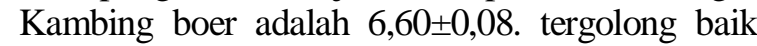
sesuai dengan hasil penelitian Lubis et al. (2013), $\mathrm{pH}$ semen segar yang didapatkan normal yaitu sekitar 6,53 $\pm 0,15$. Hasil penelitian menunjukan bahwa $\mathrm{pH}$ semen pada kambing boer sama dengan penelitian sebelumnya artinya $\mathrm{pH}$ yang didapatkan yaitu normal tidak terkontaminasi dengan bahan lain. Konsistensi semen yang didapatkan yaitu sedang-kental. Menurut Susilawati (2013), konsistensi berkorelasi positif dengan konsentrasi spermatozoa dengan penilaiannya bisa encer, sedang dan pekat.

Hasil uji mikroskopis selama penelitian diperoleh rataan motilitas massa $2+$, motilitas individu $73,33 \pm 6,06 \%$, viabilitas $81,72 \pm 7,91 \%$, abnormalitas 2,16 $\pm 0,50 \%$, dan konsentrasi sebesar $4607,30 \pm 530,79$ juta/ml. Pemeriksaan mikroskopis yang didapatkan selama penelitian menunjukan bahwa semen layak untuk dilanjutkan untuk proses pengenceran dan penyimpanan, hal ini sesuai dengan pendapat Susilawati (2013) menyatakan bahwa semen yang baik untuk dilakukan pengenceran yaitu memiliki persentase motilitas spermatozoa dalam keadaan normal tidak kurang dari $70-90 \%$, abnormalitas $<20 \%$ dan konsentrasi spermatozoa $2500 \times 10^{6}-5000 \times 10^{6} \mathrm{juta} / \mathrm{ml}$.

\section{Motilitas Individu Spermatozoa Selama Penyimpanan Dingin}

Pengamatan motilitas individu spermatozoa dilakukan setiap 24 jam sekali dimulai pada hari pertama hingga persentase motilitas individu turun menjadi $40 \%$. Motilitas individu spermatozoa dihitung berdasarkan persentase spermatozoa yang bergerak secara progresif ke depan (Susilawati, 2013). Hasil pengamatan motilitas individu spermatozoa dapat dilihat pada Tabel 2 .

Rataan motilitas individu mengalami penurunan sebanding dengan lama simpan, semakin lama waktu penyimpanan pada suhu dingin maka motilitas individu akan semakin rendah. Hasil analisis ragam menunjukan bahwa perlakuan memberikan pengaruh sangat nyata $(\mathrm{P}<0,01)$ terhadap motilitas spermatozoa kambing boer pada hari pertama sampai pada hari ke-3, akan tetapi pada perlakuan P1 dan P2 pada semua hari penyimpanan tidak menunjukkan perbedaan nyata $(\mathrm{P}>0,05)$. Berdasarkan Tabel 2 didapatkan hasil P0 mmemberikan rataan motilitas individu spermatozoa terbaik diantara semua perlakuan pada hari pertama dan kedua. Hasil analisis memperlihatkan motilitas individu spermatozoa kambing boer pada perlakuan P0 tidak berbeda nyata $(P>0,05)$ dengan perlakuan $P 3$ selama pendinginan $4-5^{\circ} \mathrm{C}$ hari ke-3, sehingga dapat dikatakan motilitas individu dengan menggunakan pengencer P3 masih memiliki motilitas individu yang setara dengan P0 sebagai kontrol pada lama simpan 3 hari. Motilitas individu pada P3 dapat bertahan hingga 3 hari penyimpanan dingin dengan motilitas $40 \%$, hasil ini lebih tinggi dibandingkan dengan penelitian sebelumnya yaitu Aziz et al. (2018) bahwa pengencer air kelapa dapat mempertahankan motilitas spermatoza kambing boer hingga penyimpanan hari ke dua.

Tabel 2. Rataan motilitas spermatozoa kambing boer selama penyimpanan dingin

\begin{tabular}{lccc}
\hline \multirow{2}{*}{ Perlakuan } & \multicolumn{3}{c}{ Rataan motilitas selama penyimpanan (\%) \pm SD } \\
\cline { 2 - 4 } & $\mathrm{H} 1$ & $\mathrm{H} 2$ & $\mathrm{H} 3$ \\
\hline P0 & $64,00 \pm 2,24^{\mathrm{b}}$ & $53,00 \pm 2,74^{\mathrm{c}}$ & $40,00 \pm 3,54^{\mathrm{b}}$ \\
P1 & $57,00 \pm 2,74^{\mathrm{a}}$ & $35,00 \pm 3,54^{\mathrm{a}}$ & $16,00 \pm 8,94^{\mathrm{a}}$ \\
P2 & $57,00 \pm 2,74^{\mathrm{a}}$ & $32,00 \pm 2,74^{\mathrm{a}}$ & $18,00 \pm 13,04^{\mathrm{a}}$ \\
P3 & $59,00 \pm 6,52^{\mathrm{ab}}$ & $47,00 \pm 4,47^{\mathrm{b}}$ & $42,00 \pm 4,47^{\mathrm{b}}$ \\
\hline
\end{tabular}

Keterangan: Notasi yang berbeda menunjukkan perbedaan yang sangat nyata $(\mathrm{P}<0,01)$ 
Pemberian kuning telur dengan persentase lebih banyak yaitu 15\% (P3) terbukti lebih mampu mempertahankan motilitas spermatozoa yang disimpan pada suhu dingin dibandingkan dengan perlakuan dengan persentase kuning telur lebih rendah yaitu 5\% (P1) dan $10 \%$ (P2), hal ini diduga karena kandungan bahan-bahan yang dibutuhkan untuk mempertahankan kemampuan spermatozoa di dalam kuning telur lebih banyak, salah satunya adalah kandungan lesitin (fosfatidil kolin). Coester et al. (2018) menjelaskan bahwa lesitin yang terkandung di dalam kuning telur ayam berperan penting dalam melapisi membran sel spermatozoa dengan mempertahankan susunan fosfolipid bilayer sel spermatozoa.

\section{Viabilitas Spermatozoa Selama Penyimpanan Dingin}

Viabilitas spermatozoa selama masa simpan mengalami penurunan secara gradual pada semua perlakuan dan kontrol selama penyimpanan dingin seperti terlihat pada Tabel 3., ini menunjukkan bahwa semakin lama semen cair disimpan pada suhu $4-5^{\circ} \mathrm{C}$ kematian spermatozoa semen cair kambing boer semakin tinggi. Viabilitas menurun dengan drastis terjadi pada lama simpan 2 hari. Penurunan viabilitas spermatozoa disebabkan karena terjadinya kerusakan membran plasma dan membran akrosom akibat cold shock selama penyimpanan pada suhu rendah (Pereira et al., 2010).

Hasil analisis ragam menunjukkan bahwa di lama simpan hari pertama dan ke-3 terdapat perbedaan sangat nyata $(\mathrm{P}<0,01)$ terhadap viabilitas spermatozoa pada semua perlakuan sedangkan pada hari kedua tidak memberikan perbedaan pengaruh yang nyata $(\mathrm{P}>0,05)$ terhadap viabilitas spermatozoa. Kondisi ini menunjukkan bahwa untuk pengencer dari air kelapa memiliki kemampuan memproteksi kehidupan spermatozoa semen cair kambing boer selama simpan dengan baik. Kemampuan protektif bahan pengencer semen cair dapat bersumber dari aktivitas antioksidan. Air kelapa mengandung antioksidan yang dapat mencegah terjadinya kerusakan oskidatif akibat peroksidasi lipid. Antioksidan dalam air kelapa ini berasal dari golongan polivenol (flavonoid) yang akan menghambat aktivitas perusakan membran spermtaozoa akibat peroksidasi lipid melalui donor atom hidrogen, eliminir senyawa ROS penyebab peroksidasi lipid (Thebo et al., 2016; Zhang et al., 2015; Sikka, 2004 ; Sanocka \& Kurpizs, 2004; Gupta et al., 2010).

Rataan persentase viabilitas tertinggi diperoleh pada perlakuan P3 diantara semua perlakuan sampai penyimpanan hari ke-3. Sedangkan, rataan persentase viabilitas terendah pada P1. Hal ini menunjukkan bahwa konsentrasi kuning telur mempengaruhi daya hidup spermatozoa dalam semen cair. Penggunaan air kelapa hijau muda saja belum mampu melindungi spermatozoa dari temperatur dingin, oleh karena itu dilakukan penambahan kuning telur. Dwitarizki et al. (2015); Salamon \& Maxweel, (2000); serta Purdy (2006) menjelaskan bahwa kuning telur merupakan bahan krioprotektan pada pengencer yang berfungsi sebagai sumber energi dan pelindung esktraseluler sel spermatozoa dari cold shock karena mengandung lipoprotein dan lesitin.

\section{Abnormalitas Spermatozoa Selama Penyimpanan Dingin}

Hasil analisis menunjukkan rataan abnormalitas spermatozoa pada semua perlakuan dengan waktu simpan pada hari-1, hari-2, dan hari-3 tidak memberikan perbedaan yang nyata $(\mathrm{P}>0.05)$. Hasil rataan persentase abnormalitas spermatozoa mengalami peningkatan selama penyimpanan pada pengencer semua perlakuan seperti pada Tabel 4. Semakin lama penyimpanan membran sel akan rusak yang berpengaruh terhadap metabolisme spermatozoa. Menurut Sarder (2004), keadaan membran sel spermatozoa yang tidak sempurna akan meningkatkan abnormalitas spermatozoa.

Tabel 3. Rataan viabilitas spermatozoa kambing boer selama penyimpanan dingin

\begin{tabular}{lccc}
\hline \multirow{2}{*}{ Perlakuan } & \multicolumn{3}{c}{ Rataan viabilitas selama penyimpanan $(\%) \pm$ SD } \\
\cline { 2 - 4 } & $\mathrm{H} 1$ & $\mathrm{H} 2$ & $\mathrm{H} 3$ \\
\hline P0 & $75,85 \pm 6,83^{\mathrm{a}}$ & $72,06 \pm 11,84^{\mathrm{a}}$ & $66,47 \pm 8,00^{\mathrm{b}}$ \\
P1 & $86,55 \pm 5,44^{\mathrm{b}}$ & $75,31 \pm 10,39^{\mathrm{a}}$ & $53,13 \pm 18,94^{\mathrm{a}}$ \\
P2 & $81,55 \pm 3,84^{\mathrm{ab}}$ & $79,08 \pm 12,14^{\mathrm{a}}$ & $58,89 \pm 12,72^{\mathrm{ab}}$ \\
P3 & $80,23 \pm 4,17^{\mathrm{ab}}$ & $73,60 \pm 6,47^{\mathrm{a}}$ & $70,49 \pm 8,21^{\mathrm{b}}$ \\
\hline
\end{tabular}

Keterangan: Notasi yang berbeda menunjukkan perbedaan yang sangat nyata $(\mathrm{P}<0,01)$ 
Tabel 4. Rataan abnormalitas spermatozoa kambing boer selama penyimpanan dingin

\begin{tabular}{lrrr}
\hline \multirow{2}{*}{ Perlakuan } & \multicolumn{3}{c}{ Rataan abnormalitas selama penyimpanan $(\%) \pm$ SD } \\
\cline { 2 - 4 } & $\mathrm{H} 1$ & $\mathrm{H} 2$ & $\mathrm{H} 3$ \\
\hline P0 & $1,29 \pm 0,90$ & $1,71 \pm 1,09$ & $2,39 \pm 1,26$ \\
P1 & $2,06 \pm 1,87$ & $2,19 \pm 1,51$ & $2,84 \pm 0,58$ \\
P2 & $1,25 \pm 0,37$ & $1,64 \pm 0,49$ & $2,41 \pm 1,10$ \\
P3 & $1,42 \pm 0,77$ & $2,01 \pm 0,79$ & $2,45 \pm 0,98$ \\
\hline
\end{tabular}

Rataan abnormalitas tertinggi sampai penyimpanan hari ke-3 yaitu pada pengencer P1 sebesar $2,84 \pm 0,58 \%$ sedangkan rataan abnormalitas paling rendah pada pengencer P0 yaitu sebesar $2,39 \pm 1,26 \%$. Selama penyimpanan sampai hari ke-3 rataan abnormalitas spermatozoa pada semua perlakuan masih dibawah $20 \%$ artinya masih baik digunakan untuk IB. Ax et al. (2008) dan Susilawati (2013) menyatakan bahwa abnormalitas yang baik untuk diaplikasikan IB yaitu memiliki nilai anormalitas spermatozoa dibawah $20 \%$. Abnormalitas yang mengalami peningkatan adalah abnormalitas sekunder, terjadi saat proses pembuatan preparat ulas seperti putusnya antara ekor dengan kepala spermatozoa, dan bentuk ekor yang melingkar serta terjadi karena lamanya penyimpanan. Ditambahkan oleh Suyadi et al. (2013) menyatakan bahwa perubahan suhu selama proses pengenceran semen dapat menyebabkan perubahan permeabilitas sel membran dinding spermatozoa, keadaan tersebut dapat menyebabkan meningkatnya abnormalitas spermatozoa.

\section{KESIMPULAN}

Berdasarkan hasil penelitian dapat disimpulkan bahwa perbedaan komposisi kuning telur pada pengencer air kelapa hijau muda memberikan perbedaan pengaruh terhadap kualitas semen cair kambing boer. Penambahan kuning telur $15 \%$ pada pengencer air kelapa hijau muda merupakan perlakuan terbaik dalam mempertahankan kualitas semen cair kambing boer sampai lama simpan 3 hari.

\section{UCAPAN TERIMA KASIH}

Penulis mengucapkan terima kasih kepada Hibah Institusi UNISMA (HI-ma) TA. 2019 yang membiayai penelitian ini, dan Laboratorium Reproduksi Fakultas Peternakan Universitas Brawijaya yang telah memberikan fasilitas tempat penelitian.

\section{DAFTAR PUSTAKA}

Ax, R., M. Dally, B. Didion, R. Lenz, C. Love, D. Varner, Hafez, \& M. Bellin. 2008. Semen Evaluation in Reproduction in Farm Animal. $7^{\text {th }}$ Edition. Edited By Hafez, E.S.E. Co. Director. Reproductive Health Kiawah Island. South Carolina, USA.

Agustian, M.F., M.N. Ihsan, \& N. Isanini. 2014. Pengaruh lama simpan semen dengan pengencer tris aminomethane kuning telur pada suhu ruang terhadap kualitas spermatozoa kambing boer. Jurnal Ternak Tropika 15(2):1-6.

Audia, R. P., M.A. Salim, N. Isnaini, \& T. Susilawati. 2017. Pengaruh perbedaan kematangan air kelapa hijau sebagai bahan pengencer yang ditambah $10 \%$ kuning telur terhadap kualitas semen cair kambing boer. Jurnal Ternak Tropika 18(1):58-68.

Aziz, A. F., M. A. Salim, N. Isnaini, A.P. A. Yekti, \& T. Susilawati. 2018. Pengaruh pengencer air kelapa tua yang berbeda varietas terhadap kuali-tas semen cair kambing Boer pada penyimpanan $3-5^{\circ} \mathrm{C}$. Jurnal Ilmu-Ilmu Peternakan 28(2):112120.

Coester, J.S., A. Sulaiman, \& M. Rizal. 2018. Daya hidup spermatozoa sapi limousin yang dipreservasi dengan pengencer tris dan berbagai konsentrasi sari kedelai. Jurnal Ilmu dan Teknologi Peternakan Tropis. 6(2):175-180.

Dwitarizki, N.D., Ismaya, \& W. Asmarawati. 2015. Pengaruh pengenceran sperma dengan air kelapa dan aras kuning telur itik serta lama penyimpanan terhadap motilitas dan viabilitas spermatozoa domba garut pada penyimpanan $5^{\circ} \mathrm{C}$. Buletin Peternakan. 39(3):149-156.

Gupta, S., L, Sekhon, Y. Kim, \& A. Agarwal, 2010. The role of oxidative stress and antioxidants in assisted reproduction. 
Current Women's Health Reviews 6(3): 227-238.

Ihsan, M.N. 2010. Inseminasi Buatan pada Kambing. Penerbit UB Press. Malang.

Lubis, T.M., Dasrul., C. N. Thasmi., \& T. Akbar. 2013. Efektifitas penambahan vitamin $\mathrm{C}$ dalam pengencer susu skim kuning telur terhadap kualitas spermatozoa kambing boer setelah penyimpanan dingin. Jurnal S Pertanian 3(1):347-361.

Pereira, G.R., E.G. Becker, L.C. Siqueira, R. Ferreira, C.K. Severo, V.S. Truzzi, J.F.C. Oliveira, \& P.B.D. Goncalves. 2010. Assesment of bovine spermatozoa viability using different cooling protocols prior to cryopreservation. Italian J Anim Sci 9(4):234-237.

Purdy. P. H. 2006. A review on goat sperm cryopreservation. Small Ruminant Research 63:215-225.

Rizal, M. 2009. Daya Hidup Spermatozoa epididimis sapi bali yang dipreservasi pada suhu $3-5^{\circ} \mathrm{C}$ dalam pengencer tris dengan konsentrasi laktosa yang berbeda. Jurnal Ilmu Ternak dan Veteriner 14(2):142-149.

Salamon, S. \& W.M.C. Maxwell. 2000. Storage of ram semen. Animal Reproduction Science 62:77-111.

Sanocka, D. \& M. Kurpisz. 2004. Reactive oxygen species and sperm cells. Reprod Biol Endocrinol 2:12.
Sarder, M. J. U. 2004. Morphological sperm abnormalities of different breeds of ai bull and its impact on conception rate of cows in AI programme. Bang J Vet Med 2(2):129-135.

Sikka, S.C, 2004. Role of oxidative stress and antioxidants in andrology and assisted reproductive technology. Journal of Andrology 25(1):5-18.

Susilawati, T. 2013. Pedoman Inseminasi Buatan Pada Ternak. UB Press. Malang.

Suyadi., A.Rachmawati, \& N. Iswanto. 2013. Pengaruh A-Tocopherol yang berbeda dalam pengencer dasar tris ainomethane kuning telur terhadap kualitas semen kambing boer yang disimpan pada suhu $5^{\circ} \mathrm{C}$. Jurnal Ilmu Ilmu Peternakan 22(3):1-8.

Thebo, N.K., A. A. Simair \& G. S, Mangrio, 2016. Antifungal potential and antioxidant efficacy in the shell extract of Cocos nucifera (L.) (Arecaceae) against pathogenic dermal mycosis. Medicines 3(12):1-12.

Vigliar R., V. L. Sdepanian, \& U. FagundesNeto. 2006. Biochemical profile of coconut water from coconut palms planted in an inland region. Jornal de Pediatria, 82(4):308-312.

Zhang, Y.J., R.Y, Gan., S, Li., Y, Zhou., An $\mathrm{Na}$ Li., D. P, Xu \& H.B, Li. 2015. Antioxidant phytochemicals for the prevention and treatment of chronic diseases: review. Molecules 20:38-56. 